\title{
Assessment of Institutional Quality in Resource-Rich Caspian Basin Countries*
}

\author{
Ingilab Ahmadov ${ }^{\dagger}$ Jeyhun Mammadov ${ }^{\ddagger}$ Kenan Aslanli ${ }^{\S}$ \\ June 4, 2013
}

\begin{abstract}
Natural resource dependence is believed to have potential impact on institutional development, and there is growing consensus in the academic literature that institutional weakness is central to the explanation of the negative effects of resource booms. Generally, the quality of institutional framework and natural resource dependence interact mutually. Natural resources rents can damage institutions by removing incentives to conduct reforms and even to establish a well-functioning bureaucracy. Also, weak institutional quality is the ultimate cause for a disadvantageous management framework of natural resources and process of converting revenue flows into economic development. This paper examines the connection between institutional quality and resource dependence in resource-rich Caspian Basin countries (Azerbaijan, Kazakhstan, Russia, Turkmenistan) with transition economies. The analysis for the total natural resources rents suggests that, in aggregate, revenues on total natural resources have a negative impact on government effectiveness.
\end{abstract}

Keywords: Resource curse, institutional quality, government effectiveness.

*Financial support from the Revenue Watch Institute (RWI) is gratefully acknowledged.

$\dagger$ Department of Economics and Management, Khazar University, 122 Bashir Safaroglu Str., Baku, Azerbaijan. E-mail: ingilab@khazar.org

${ }^{\ddagger}$ Department of Economics and Management, Khazar University, 122 Bashir Safaroglu Str., Baku, Azerbaijan. E-mail: jmammadov@khazar.org

§Public Finance Monitoring Center, Azerbaijan. E-mail: kenan@pfmc.az 


\section{Introduction}

\section{The role of institutional quality in the "resource curse"}

Due to the assessment of international financial institutions, in the past decades, natural resources played a crucial role in the economic development of many resource-rich countries. Until the 1980s, natural resource abundance was considered an advantage by economists. However, theoretical and empirical research starting in the 1980s reached conclusions to the contrary, suggesting that natural resources might be an economic curse rather than a blessing. "The phrase 'resource curse' was coined and, perhaps because of its paradoxical connotation, caught on in both academic and policy circles. The current literature distinguishes between no less than three different 'dimensions' of the resource curse: resources are associated with slower economic growth, violent civil conflict, and undemocratic regime types" (Brunnschweiler and Bulte, 2008). ${ }^{1}$ Various studies suggest that resource dependent countries have, on average, lower long-run growth rates than countries with a more diversified export structure. It is possible that resource dependence may impact institutional development, which can determine a country's growth potential following resource booms. At the same time there is growing consensus in the academic literature that institutional weakness is central to the explanation of the negative effects of resource booms (Collier and Hoeffler, 2009). In this regard, the existing literature distinguishes formal and informal institutions. With respect to natural resources, formal institutions could include legislation on the natural resource sectors or a fiscal equalization formula for transfers from resource-rich provinces to those that are resourcepoor. But informal institutions encompass the unwritten rules structuring behavior.

Regarding Douglas North's eminent definition, "institutions are the humanly devised constraints that structure political, economic and social interaction" (North, 1991). Also, "institutions might be defined as a set of social factors, rules, beliefs, values and organizations that jointly motivate regularity in individual and social behavior" (see Alonso and Garcimartín, 2009; Greif, 2006). Institutions are the "rules of the game" that structure political, economic, and social interactions. "Why Nations Fail" by Daron Acemoglu and James A. Robinson (2012) focuses on "the process of institutional drift that produce political and economic institutions that can be either inclusive - focused on power-sharing, productivity, education, technological advances and the well-being of the nation as a whole; or extractive - bent on grabbing wealth and resources away from one part of society to benefit another" (Acemoglu and Robinson, 2012). ${ }^{2}$

Generally, quality of institutional framework and natural resource dependence interact mutually. On the one hand, natural resources rents can damage governance institutions by removing incentives to reform and even to establish a well-functioning bureaucracy (Hartford and Klein,

\footnotetext{
${ }^{1}$ On economic growth, refer to Sachs and Warner (1997), Mehlum et al. (2005). On conflict, refer to Collier and Hoeffler (1998), Collier et al. (2007), Ross (2004a,b), Lujala (2005). On regime type and institutions more broadly, refer to Leite and Weidmann (2002), Jensen and Wantchekon (2004).

${ }^{2}$ http://www.rand.org/blog/2012/04/book-review-why-nations-fail-by-daron-acemoglu-and.html
} 
2005). On the other hand, weaker institutional quality is cause for an objectionable management framework of natural resources and process of converting revenue flows into sustainable development. Based on these assumptions, we can assert that it is relatively complicated to identify a "cause-effect relationship" between institutional quality and oil-gas revenue flows in resource dependent countries. Natural resource-rich post-Soviet countries (Azerbaijan, Russia, Kazakhstan, and Turkmenistan) share a common historical legacy and had a very similar weak institutional and regulatory framework in both the political and the economic sphere before their resource booms (1991-2001). This paper examines the impact of oil-gas revenue flows on quality of institutions during and after resource booms (2001-2011).

Barma, Kaiser, Le and Viñuela (2012) emphasize that the quality of a country's institutions is central in the resource paradox and institutional quality tends to vary along with levels of economic development. They state that "a simple empirical fact often ascribed as a major dimension of the resource curse is that resource-dependent countries are endowed with poorer institutional quality than they should have, given their income levels. Holding gross domestic product (GDP) constant, resource-dependent countries perform less well in governance indicators demonstrating the institutional dimension of the resource curse" (Barma, Kaiser, Le, and Viñuela, 2012). Relevant "policies could be effective in leveraging natural resource-led development only when they are compatible with the level of institutional quality and the political economy context of the country in question" (Barma, Kaiser, Le, and Viñuela, 2012). Authors preferred to use the "Voice and Accountability" indicator from the Worldwide Governance Indicators dataset.

Mehlum, Moene and Torvik (2006) argue that "quality of institutions determines whether countries avoid the resource curse or not: the combination of grabber friendly institutions and resource abundance leads to low growth; however, producer friendly institutions help countries to take full advantage of their natural resources." Authors use the rule of law as a common measure of institutional quality confirming the evidence that a dangerous mix of weak institutions and resource abundance causes the resource curse. Their main focus in the theoretical part of the study is the allocation of entrepreneurs between production and unproductive rent extraction- grabbing- which the harms economy. Depending on the quality of institutions, lootable resources may or may not induce entrepreneurs to specialize in grabbing. In their applied model the institutional quality is captured by the parameter, which reflects the degree to which the institutions favor grabbers versus producers (see Mehlum, Moene and Torvik, 2006).

Ross (2012) explains that government institutions are themselves damaged by oil revenues. So, if oil makes government less effective, it could impair their ability to maintain countercyclical policies. He distinguishes two ways this could occur. First, revenue volatility could shorten the government planning horizon, which would subvert major investment projects. The second way is a syndrome called "bureaucratic overstretch," meaning that a government's revenues expand more quickly than its capacity to efficiently manage them. Ross argues that "resource-rich countries sometimes receive windfalls that overwhelm their bureaucratic capacity, amplifying the danger that 
they will be poorly used." He described the tendency that "rent seizing" occurs when politicians sweep aside institutional constraints to gain control of how a valuable resource is allocated and regulated - giving them the power to use it for patronage or corruption. Ross states that many scholars make a more ambitious claim that petroleum wealth leads to "bad institutions," making governments weaker, more corrupt, less competent and less able to maintain wise fiscal policies. Ross claims in his recent study that "there is little prima facie evidence that oil revenues tend to hurt government quality" and "if extracting oil were bad for government institutions, it should be seen a negative correlation between a country's oil income and the quality of its government" (Ross, 2012). Regarding his calculations, government effectiveness declined in the oil states more than in non-oil states from 1996 to 2006, but differences were not statistically significant. He put forward a sound hypothesis that social scientists "lack measures of a government's actual performance" and they often "rely on measures of a government's perceived performance." World Bank has already developed a unique conceptual tool in order to measure governance and institutional framework entitled "World Governance Indicators" where authors Kaufmann, Kraay and Mastruzzi (2010) first portrayed the existing notions of governance and then defined the new definition of governance as "the traditions and institutions by which authority in a country is exercised including:

(a) The process by which governments are selected, monitored and replaced;

(b) The capacity of the government to effectively formulate and implement sound policies;

(c) The respect of citizens and the state for the institutions that govern economic and social interactions among them."

The authors have marked two measures of governance corresponding to each of these three areas (six dimensions of governance): 


\begin{tabular}{|c|c|}
\hline GOVERNANCE AREAS & INDICATORS \\
\hline \multirow[t]{2}{*}{$\begin{array}{l}\text { (a) The process by which } \\
\text { governments are selected, } \\
\text { monitored, and replaced: }\end{array}$} & $\begin{array}{l}\text { 1. Voice and Accountability (VA) - capturing percep- } \\
\text { tions of the extent to which a country's citizens are able } \\
\text { to participate in selecting their government, as well as } \\
\text { freedom of expression, freedom of association, and a free } \\
\text { media. }\end{array}$ \\
\hline & $\begin{array}{l}\text { 2. Political Stability and Absence of Violence/Terrorism } \\
\text { (PV) - capturing perceptions of the likelihood that the } \\
\text { government will be destabilized or overthrown by un- } \\
\text { constitutional or violent means, including politically- } \\
\text { motivated violence and terrorism. }\end{array}$ \\
\hline \multirow[t]{2}{*}{$\begin{array}{l}\text { (b) The capacity of the } \\
\text { government to effectively } \\
\text { formulate and implement } \\
\text { sound policies: }\end{array}$} & $\begin{array}{l}\text { 3. Government Effectiveness (GE) - capturing percep- } \\
\text { tions of the quality of public services, the quality of the } \\
\text { civil service and the degree of its independence from po- } \\
\text { litical pressures, the quality of policy formulation and } \\
\text { implementation, and the credibility of the government's } \\
\text { commitment to such policies. }\end{array}$ \\
\hline & $\begin{array}{l}\text { 4. Regulatory Quality (RQ) - capturing perceptions of } \\
\text { the ability of the government to formulate and implement } \\
\text { sound policies and regulations that permit and promote } \\
\text { private sector development. }\end{array}$ \\
\hline \multirow[t]{2}{*}{$\begin{array}{l}\text { (c) The respect of citizens } \\
\text { and the state for the in- } \\
\text { stitutions that govern eco- } \\
\text { nomic and social interac- } \\
\text { tions among them: }\end{array}$} & $\begin{array}{l}\text { 5. Rule of Law (RL) - capturing perceptions of the ex- } \\
\text { tent to which agents have confidence in and abide by the } \\
\text { rules of society, and in particular the quality of contract } \\
\text { enforcement, property rights, the police, and the courts, } \\
\text { as well as the likelihood of crime and violence. }\end{array}$ \\
\hline & $\begin{array}{l}\text { 6. Control of Corruption (CC) - capturing perceptions of } \\
\text { the extent to which public power is exercised for private } \\
\text { gain, including both petty and grand forms of corruption, } \\
\text { as well as "capture" of the state by elites and private } \\
\text { interests. }\end{array}$ \\
\hline
\end{tabular}

Also, institutional quality can be measured using the Economic Freedom of the World index published by Gwartney and Lawson (2003). The EFW index has been used in a number of relevant studies. The EFW index measures institutional quality in five major areas: (1) size of government; (2) legal structure and security of property rights; (3) access to sound money; (4) 
exchange with foreigners; (5) regulation of capital, labor, and business (see Gwartney, Holcombe and Lawson, 2004). Zhuang, Dios, and Lagman-Martin (2010) argue that the concept of "quality" of governance institutions is multidimensional and it is possible that certain aspects of institutional quality are more relevant or critical than others in determining economic performance for specific countries during specific periods. Institutions and their implied governance results may well be "supply-side" factors that drive economic growth; they are also attendant products of growth itself - partly because rising incomes and education levels create a "demand" for them (Zhuang, Dios and Lagman-Martin, 2010). Qian (2012) revealed that countries default more often when they lack rules and strong institutions to curb the influence of powerful groups on government policies. That is because in a polarized government, each powerful group makes decisions without considering the impact on other groups (see Qian, 2012). Alonso and Garcimartin (2004) analyzed the four characteristics which define institutional quality: static efficiency, dynamic efficiency, credibility and predictability. Also, they investigated the determinants of institutional quality and the determinants under analysis were separated into two groups (first, "historical" features of countries: colonial origin, geographic location or legal tradition; second, characteristics of institutional quality). Their empirical research suggests that the quality of institutions depends essentially on development level, income distribution, tax revenue and education (see Alonso and Garcimartin, 2009). They argued that variables, such as natural resource endowments, impact institutional quality indirectly by affecting income distribution and decreasing tax revenue. Mehrara, Alhosseini, and Bahramirad (2011) found that "oil, as one the most important natural resources, constitutes a major source of income for many countries, and depending on the institutions of the country, can contribute to the long term economic growth of that country or lead to the poor long run economic performance." They suggest to the international donor organizations that "solutions offered for different countries for the control and prevention of the oil effects on economy should be diverse depending on the institutions of that country." Their study considered the growth rate of oil prices in recent years and the probability of negative effects for these revenues on countries with the worst institutional quality. They distinguish two solutions among the proposals offered on direct distribution of resource revenues among people and privatization of the oil resources to countries with the worst institutional quality (Mehrara, Alhosseini, and Bahramirad, 2011). De Rosa and Iootty (2012) examine in their paper whether natural resource dependence has a negative influence on various indicators of institutional quality when controlling for the potential effects of other geographic, economic and cultural initial conditions (Rosa and Iootty, 2012). They analyzed a panel of countries from 1996 to 2010 and indicated that "a high degree of resource dependence, measured as the share of mineral fuel exports in a country's total exports, is associated with worse government effectiveness, as well as with reduced levels of competition across the economy." 
Resource dependence vs. government effectiveness (De Rosa and Iootty, 2012)

"Estimation of short and long run elasticity suggest that government effectiveness and the intensity of domestic competition decrease over time as the dependence on natural resources gradu ally increases. The effect seems quite relevant, with a $1 \%$ increase in the average worldwide share of fuel exports in total exports leading to a $0.13 \%$ decrease in government effectiveness in the short run, and to a $0.20 \%$ decline in the long run. When considering competition in the local market, an increase of $1 \%$ in the share of fuel exports in total exports is associated with a decrease of $0.69 \%$ in the competition indicator in the short run and of $0.93 \%$ in the long run. The effect in the case of Russia for government effectiveness appears smaller than the global average but much larger than in a comparator economy such as Canada. A $1 \%$ increase in the share of fuel exports in total exports of the country would lead to a $0.15 \%$ decrease in government effectiveness in the short run, and to a $0.17 \%$ reduction in the long run. This compares to a decrease in Canada of $0.07 \%$ in the short run and $0.08 \%$ in the long run."

In current framework provided by De Rosa and Iootty (2012), the first indicator of institutional quality was based on the Worldwide Governance Indicators (WGI) compiled by the World Bank. As mentioned before, these indicators emphasize different aspects of governance (voice and accountability, political stability and absence of violence, government effectiveness, regulatory quality, rule of law, and control of corruption). The second indicator of institutional quality captured the indirect effect of resource dependence in terms of undermining a level playing field in the economy. The authors preferred to use the index of competition in local markets from the Global Competitiveness Index (GCI) compiled by the World Economic Forum.

Cherif and Hasanov (2012) developed a model for optimal consumption, saving and investment policies of oil exporters. But many determinants of growth, development and an effective allocation of resources are not explicitly specified in their model. These include quality of institutions, educational attainment, innovation, and economic diversification. They concluded that "an increase in the productivity parameter proxying for better institutions and education would contribute to higher growth in model" (Cherif and Hasanov, 2012). Arezki, Hamilton and Kazimov (2011) examined the performance of commodity-exporting countries in terms of macroeconomic stability and growth in a panel of up to 129 countries during the period 1970-2007. They found that on average government spending in commodity-exporting countries has been pro-cyclical which also can be considered a result of non-relevant policy-making and institutional arrangements. Finally, "the effects of resource windfalls on macroeconomic stability and economic growth are moderated by the quality of political institutions" (Arezki, Hamilton and Kazimov, 2012). This aspect has 
recently been the subject of extensive study by various scholars (see Heinrich, 2012).

\section{The case of resource-rich Caspian basin countries}

The Post-Soviet aspect of the interaction of resource revenues and institutional quality has been relatively less investigated. There is a very small number of works written by researchers from these countries. The main reason for this lack is the comparatively short period of existence (a bit more than 20 years) of post-Soviet countries as opposed to other resource-rich countries. "When the Soviet Union collapsed in 1991, it generated not only fifteen newly independent states, but also a new set of petroleum-rich developing countries - Azerbaijan, Kazakhstan, The Russian Federation, Turkmenistan and Uzbekistan. Alongside their petroleum-poor counterparts, these five former Soviet Republics inherited universally weak institutions - most notably fiscal regimes. Their experience suggests not only that weak institutions are not endogenous to mineral but also that even those mineral-rich states that do not inherit strong institutions can nonetheless build them" (Luong and Weinthal, 2010, p.4). A new system of institutions, which in many ways ought to be re-established, is springing up in the period of transformation. "During the market reforms of the 1990s, post-Soviet countries not only experienced transformation recession, but also encountered problems of building new institutions against the background of a decline in state capacity that affected the processes of state building. ${ }^{3}$ The Soviet past of these countries not only served as a counterproductive basis for the establishment of efficient institutions, but in many ways was the catalyst of rent-seeking behavior of political and economic actors who shared the former Soviet assets between them. ${ }^{4}$ Unsurprisingly, post - Soviet institution building led to a partial and low-level equilibrium of the 'rules of the game "' (Gel'man and Marganiya, 2010). ${ }^{5}$

Although the assessments of the transformation works in that period are discrepant, many authors nevertheless admit that the foundation of a new institutional system of post-Soviet space was laid in that specific period, particularly in Russia. "The first period came during the 1990s and can rightfully be called a period of transformation. It was marked, first and foremost, by largescale institutional changes and by a no less substantial restructuring of the economy. Post-Soviet Russia's major political and economic institutions were formed, in their first outlines, precisely during these years" (Kiril Rogov, 2011). ${ }^{6}$

It is worth mentioning that the beginning of this work was accompanied by political, national, territorial and social conflicts in these countries (Azerbaijan, Russia) which seriously complicated

\footnotetext{
${ }^{3}$ Vadim Volkov, Violent Entrepreneurs: The Role of Force in the Making Russian Capitalism (Ithaca, N.Y: Cornel University Press, 2002): Timothy Colton and Stephen Holmes, eds., The State After Communism: Governance in the New Russia (Lanham, Md., Rowman and Littlefield, 2006) ; Gerald Easter, "The Russian State in the Time of Putin," Post-Soviet Affairs, 24, no 3 (2008), 199-230

${ }^{4}$ See chapter 5 in Gel'man and Marganiya (2010).

${ }^{5}$ Joel Hellman "Winners Take all: The Politics in Partial Reforms in Post-Communist Transitions," World Politics, 50, no. 2 (1998), 203-34.

${ }^{6}$ Russia in 2020: Scenarios for the future. Carnegie Endowment for International Peace. Ch.7., p. 125
} 
the stable work of reformation of the institutional system inherited from the USSR (see Kirill Rogov, 2011).

In the nineties of the last century, countries in review had to commence transformative actions, and those years were also considered extremely unfavorable for the oil-producing nations. In the late nineties oil prices dropped to a record low level (10 USD per barrel). Obviously at this juncture, post-Soviet resource-rich countries could hardly expect the positive outcome of institutional reformation. In that unstable period of time, the main headache was still a shortage of financial resources of the state and lack of substantial investments to the economy. "As long as stability is the leadership priority, there will be no fundamental reform of this noncompetitive industrial structure. The reform efforts that are commonly called 'modernization' will instead focus on improving the static efficiency of the existing structure. The dilemma is that upgrading the current structure in this way will make the more fundamental challenge of restructuring even more difficult" (Gaddy and Ickes, 2011). ${ }^{7}$

However, we have to mention the role of personality, which played a colossal role in the difficult period of transformation of the post-Soviet area. In many cases institutions were created by virtue of these personalities meeting their adequate goals and responsibilities. As it was mentioned by Douglass North, "Institutions are not ... usually created to be socially efficient; rather..., (they) are created to serve the interest of those with the bargaining power to devise new rules" (North, 1990). A typical example at this point can be the roles of Heydar Aliyev and Vladimir Putin in the modern histories of Azerbaijan and Russia, respectively.

In parallel with the above, we should mention that the post-Soviet countries that are rich in hydrocarbons and heterogeneous in the history of these resources, as well as in their traditions and societies, also differ with regards to their developed institutional systems. Russia is historically distinguished by its inadequately cumbersome and inflexible bureaucracy. For example, during the government rule of Heydar Aliyev in Azerbaijan, he undertook a sharp redundancy policy on the state apparatus and launched a relatively small apparatus. One may assume that a rational approach to the institutions in Azerbaijan could have led to their effective existence. However, the quality of institutions here based on the global indicators has not yet reached an adequate level.

There are also so-called "institutional compromises," which in the opinion of experts are explained by the existence of the oligarchic groups in the reviewed countries with discrepant interests (see Gelman, 2011). ${ }^{8}$ In the work "Institution building and 'institutional traps' in Russian politics," Vladimir Gelman comprehensively examines the Russian way of the institutional development and arrives at the conclusion that Russia was institutionally entrapped (see Gelman, 2011, p.215). He investigates the process of getting entrapped in detail and identifies two stages, i.e. 1 - the fight of elites and cartel agreement (1993-2000) and 2 - the so-called forced consensus (2000-2010). In his work he places heavy emphasis on the problem of absence of any effective institutional limitations

\footnotetext{
${ }^{7}$ Ibid., Ch.9.p.166

${ }^{8}$ Ibid., Ch.11., p.215
} 
in post-Soviet countries, which on the one hand is linked to the weakness of democratic institutions and on the other hand to the absolute power of the executive authorities operating the large revenues from the sale of hydrocarbons in the global markets. Absence of institutional limitations leads to the desired institutional balance and puts a serious threat on the long-term development of the country.

In the work "Mechanisms of resource curse, economic policy and growth," Polterovich, Popov and Tonis (2008), along with some general issues of resource curse, largely focus on institutional aspects of resource-rich countries indicating interrelation between institutional development and economic growth. It is unequivocally stated that poor institutions aggravate the already difficult situation in these countries and resource curse is expressed by virtue of ineffective management of the revenues from the export of natural resources. As a result, economic growth slows down and long-term country development becomes an open question.

Polterovich, Popov and Tonis (2008) distinguish three channels (macroeconomic, institutional and technological) of "resource curse." In the institutional channel, they indicate the struggle for resource rent and instability of democracy ( p.8).

Some foreign authors pay special attention to the Central Asian countries, many of which are rich in natural resources. The attitude of the authorities, system of public administration and particularly the established practice of undemocratic government ruling has always remained a matter of intense interest. Incomparably large amounts of resources and their impact on the system and methods of institutional development in the region are thoroughly examined in the work of Pauline Jones Luong and Erika Weinthal "Oil is Not a Curse." "Alongside their petroleum counterparts, these five former Soviet republics [Azerbaijan, Kazakhstan, Russian Federation, Turkmenistan and Uzbekistan] inherited universally weak institutions- most notably fiscal regimes. Their experience suggests not only that weak institutions are not endogenous to mineral wealth but also that even those mineral-rich states that do not inherit strong institutions can nonetheless build them. Most importantly, the divergent development of fiscal regimes in each of these states from the early 1990s through 2005 also provides ample support for our contention that institutions in mineralrich states are not a product of their wealth per se, but rather ownership structure- that is, who owns and controls the mineral sector" (Luong and Weinthal, 2010, p.4).

The rest of the paper is organized as follows: in the next section, we present a macroeconomic review of the selected countries. Section 3 presents empirical specification and data description. Sections 4 and 5 present and analyze estimation results. Section 6 offers conclusions.

\section{Macroeconomic Performance and Prospects}

The analysis of macroeconomic performance is largely based on information and data obtained from the European Bank for Reconstruction and Development (EBRD) Regional Economic Prospects 
2010-2013 and Transition Report 2010. Our analysis suggests that the key challenge for Azerbaijan, Russia, Kazakhstan and Turkmenistan is to diversify their economies. As Porter (2004) noted, "natural resources result from endowments, not economic competitiveness... countries with low levels of productivity are more dependent on natural resource exports". Hence, relevant economic policies (mentioned below in country overviews) to increase productivity are essential in order to meet this aim. The main macroeconomic and vulnerability indicators are as follows:

Table 1: Main macroeconomic indicators

\begin{tabular}{|c|c|c|c|c|c|c|c|c|c|c|c|c|c|c|c|c|}
\hline \multirow[t]{2}{*}{ Countries } & \multicolumn{5}{|c|}{$\begin{array}{c}\text { GDP growth (average) } \\
\text { (year over year percent change) }\end{array}$} & \multicolumn{3}{|c|}{$\begin{array}{c}\text { Inflation (average) } \\
\text { (year over year percent } \\
\text { change) }\end{array}$} & \multicolumn{2}{|c|}{$\begin{array}{c}\text { Fiscal } \\
\text { Balance } \\
\text { (gen. gov; } \% \\
\text { of GDP) }\end{array}$} & \multicolumn{2}{|c|}{$\begin{array}{c}\text { GG } \\
\text { Debt/revenues }\end{array}$} & \multicolumn{2}{|c|}{$\begin{array}{l}\text { Current } \\
\text { Account } \\
\text { (\% of GDP) }\end{array}$} & \multicolumn{2}{|c|}{$\begin{array}{c}\text { Net FDI } \\
\text { (\% of GDP) }\end{array}$} \\
\hline & 2009 & 2010 & 2011 & 2012 & 2013 & 2010 & 2011 & 2012 & 2010 & 2011 & 2010 & 2011 & $\begin{array}{l}201 \\
0\end{array}$ & 2011 & 2010 & 2011 \\
\hline Azerbaijan & 9.3 & 5.0 & 0.1 & 2.2 & 4.0 & 5.7 & 8.5 & 1.0 & 13.6 & 11.3 & 24.4 & 21.9 & 27.7 & 26.5 & 0.6 & 1.4 \\
\hline Turkmenistan & 6.1 & 9.2 & 14.7 & 11.1 & 10.0 & 4.8 & 5.8 & 4.5 & 2.3 & 3.6 & 66.0 & 38.6 & $\begin{array}{l}- \\
11.7\end{array}$ & 2.0 & 18.2 & 12.1 \\
\hline
\end{tabular}

Source: Regional Economic Prospects in EBRD Countries of Operations: January 2013

Table 2: Vulnerability indicators

\begin{tabular}{|c|c|c|c|c|c|c|c|c|c|c|c|}
\hline \multirow{3}{*}{ Countries } & \multicolumn{4}{|c|}{$\begin{array}{c}\text { Public and External Debt } \\
\text { (\% of GDP) }\end{array}$} & \multicolumn{4}{|c|}{ Gross reserves } & \multicolumn{2}{|c|}{ Country risk } & \multirow{3}{*}{$\begin{array}{l}\text { Unemployment } \\
\% \text { (latest } \\
\text { available) } \\
\end{array}$} \\
\hline & \multirow[b]{2}{*}{$\begin{array}{l}\text { Govern } \\
\text {-ment } \\
\text { (end } \\
2011 \text { ) }\end{array}$} & \multicolumn{3}{|c|}{ External } & \multirow[b]{2}{*}{$\begin{array}{l}\text { Billions } \\
\text { US\$ } \\
\text { (latest) }\end{array}$} & \multicolumn{3}{|c|}{ In percent of GDP } & \multicolumn{2}{|c|}{ Latest } & \\
\hline & & $\begin{array}{l}\text { Total } \\
\text { (end } \\
\text { 2011) }\end{array}$ & $\begin{array}{l}\begin{array}{l}\text { Private } \\
\text { (end } \\
2011 \text { ) }\end{array}\end{array}$ & $\begin{array}{l}\text { Short term } \\
\text { (remaining } \\
\text { maturity) }\end{array}$ & & GDP & $\begin{array}{l}\text { Short } \\
\text { term } \\
\text { debt }\end{array}$ & $\begin{array}{l}\text { Month } \\
\text { of } \\
\text { prosp. } \\
\text { imports }\end{array}$ & $\begin{array}{l}\text { S\&P } \\
\text { sovereign } \\
\text { country } \\
\text { ratings } \\
\end{array}$ & $\begin{array}{l}\text { Fitch } \\
\text { Sovereign } \\
\text { country } \\
\text { ratings } \\
\end{array}$ & \\
\hline Azerbaijan & 10.0 & 7.3 & -- & -- & 10.7 & 16.5 & -- & 7.2 & BBB- & BBB- & 6.0 \\
\hline Russia & 12.0 & 27.6 & 25.2 & 8.2 & 537.6 & 27.0 & 307.8 & 12.7 & BBB & BBB & 5.4 \\
\hline Kazakhstan & 10.5 & 66.5 & 63.5 & 7.4 & 28.3 & 15.0 & 174.5 & 5.1 & $\mathrm{BBB}+$ & $\mathrm{BBB}+$ & 5.3 \\
\hline Turkmenistan & 7.3 & 7.3 & 0.0 & 0.7 & -- & -- & -- & -- & -- & -- & -- \\
\hline
\end{tabular}

Source: Regional Economic Prospects in EBRD Countries of Operations: January 2013 


\section{Azerbaijan}

Limited integration into the world market insulated Azerbaijan from most of the impact of the 2008-2009 crisis (UNICEF Country Profile, 2010). The largest impact was the decline in the cost of oil. Despite this, the Azerbaijan economy continues to grow, but at a slower rate. GDP growth was recorded at 34.5 percent in 2006, 25 percent in 2007, 10.8 percent in 2008 and 9.3 percent in 2009 (see IMF World Economic Outlook Database, 2013). High economic growth in 2006-08 was associated with large oil exports. However, declining oil prices during the financial and economic crisis revealed the risks posed by high oil dependence. The crisis underlined the economy's vulnerability to fluctuations in global commodity prices as the terms of trade worsened severely. Annual growth slowed down to $0.1 \%$ in 2011, as oil and gas production reached a plateau. Real GDP growth is forecasted to improve to $4 \%$ in 2013, but the current global economic slowdown poses some challenges and a threat for the development of Azerbaijani economy as oil prices remain fluctuating, highlighting Azerbaijan's heavy dependence on energy exports. Therefore, the key challenge in front of Azerbaijan is to diversify its economy. To promote export diversification and increase non-oil exports, it is crucial to improve the business environment, regional development, encourage competition and attract more foreign investors in non-oil sectors (EBRD Transition Report, 2010). Foreign direct investment into the non-oil sector still remains at a low level. On the other hand, macroeconomic risks are lessened by a very strong fiscal position.

\section{Russia}

After suffering a 7.9 percent contraction in its GDP growth in 2009, Russia's economy emerged from recession with a GDP growth of 4.3 percent recorded in 2010. According to EBRD, economic recovery has been triggered by higher oil prices, a large fiscal stimulus, pension increases and ample liquidity in the banking system. GDP growth is forecasted to have reached 3.5 percent in 2012 and expected to remain around 3.5 percent in 2013 (see EBRD Regional Economic Prospects, 2013). However, the growth rate remains below half of the growth rate before the 2008-2009 financial and economic crisis.

At present, the challenge for Russia is to strengthen its fiscal position without putting economic recovery at risk. This is very crucial, as the depletion of fiscal reserves can increase the volatility of the economy to fluctuations in global commodity prices given the fact that Russia's economy remains heavily dependent on natural resource exports (particularly, oil and gas). Therefore, to reach a sustainable growth path, there is a great need to diversify the economy and wean the country off its excessive dependence on oil and gas revenues. This objective necessitates improving the business environment and regional development, and proliferating FDI friendly policies. 


\section{Kazakhstan}

In response to global economic slowdown, economic growth in Kazakhstan has decelerated. GDP growth was recorded at 8.9 percent in 2007, 3.2 percent in 2008 and 1.2 percent in 2009 (see IMF World Economic Outlook Database, 2013). The Kazakhstan economy emerged from recession in the end of 2009 driven by extractive industries, and the GDP expanded by 7.3 percent in 2010 . GDP growth is forecasted to have slowed down from 7.5 percent in 2011 to 5 percent in 2012, and expected to improve to 6 percent in 2013 due to a new phase of the Kashagan offshore oil field (EBRD Regional Economic Prospects, 2013). Growth is supported by high commodity prices and fiscal stimulus.

In order to reach a long-term sustainable growth path, the key challenge before Kazakhstan is to diversify the economy and modernize industry and service sectors. To meet this aim, more state investment in infrastructure, education, and industrial projects as well as the active involvement of the private sector are required (EBRD Transition Report, 2010).

\section{Turkmenistan}

"Turkmenistan remains the least reformed of all transition countries and has only started the process of transition in the last two years" (EBRD Transition Report, 2010). Turkmenistan has limited integration with world markets. Due to its dependence on hydrocarbons, Turkmenistan has not been considerably affected by the 2008-2009 financial and economic crisis. GDP growth moderated from 10 percent in 2008 (14.8 percent according to IMF) to 6.1 percent in 2009, rose by 14.7 percent in 2011 (due to increased gas exports to Iran and China), and is forecast to reach 10 percent in 2013. However, it is assumed that the economy will remain strong in the medium term, supported by abundant gas reserves.

Therefore, key challenges are to wean the country off its excessive dependence on natural resources and modernize its industry. These objectives necessitate attracting private sector investment. In Turkmenistan, access of small and medium sized enterprises to finance is difficult as state dominance in the financial system remains large. Therefore, attracting private banks could improve liquidity and efficiency in the banking sector.

\section{Empirical Specification and Data Description}

Using a panel dataset containing information on government effectiveness, we establish the determinants of government effectiveness in Azerbaijan, Russia, Kazakhstan, and Turkmenistan over the period 1996 to 2011. The multiple linear regression models to be estimated are as follows:

$$
\operatorname{GovEf}_{i t}=\alpha_{1} \text { OilRent }_{i t}+\alpha_{2} G D P p c_{i t}+\alpha_{3} Z+n_{i}+r_{t}+e_{i t}
$$


Government effectiveness, denoted by GovEf, "reflects perceptions of the quality of public services, the quality of the civil service and the degree of its independence from political pressures, the quality of policy formulation and implementation, and the credibility of the government's commitment to such policies" (World Bank). The variable of interest is OilRent (oil rents as a percentage of GDP), which measures the difference between the value of crude oil production at world prices and total costs of production. GDP per capita, denoted by GDPpc, is a proxy for the stage of development. It is assumed that the institutional quality is associated with the stage of development of each country. $n$ is a country fixed effect, $r$ is a time fixed effect and $e$ is an error term. The other control variables that are assumed to influence government effectiveness are given in $Z$ matrix. These control variables include Polity IV and Foreign Direct Investment (FDI) stock as a percent of GDP.

Polity IV is a politics index on political freedom, an indicator of democracy. The data on the politics index is taken from the Polity IV Project supported by the Political Instability Task Force, Societal-Systems Research, and Center for Systemic Peace. The indicator for democracy is the ranking based on the Polity score for the level of democracy, ranging from -10 (strongly autocratic) to $10+$ (strongly democratic).

It is assumed that the positive externality in institutional quality is captured by the spillovers from FDI. These spillovers include not only information on technologies, but also management methods brought through foreign direct investment. The spillovers are also the determinants of the growth rate of human capital, which has an indispensable role in institutional quality. ${ }^{9}$ The reason for considering FDI stock instead of FDI inflows is that technological and knowledge spillovers are captured from stock variables. Therefore, in our opinion, an increase in oil revenues is highly associated with foreign investment in oil sector. On the other hand, the literature suggests that the quality of government infrastructure is an important determinant of FDI inflows (see Kirkpatrick, Parker and Zhang, 2006; Globerman, Shapiro, 2002; Hellman, Jones, and Kaufmann, 2000). Considering causality, private foreign investment in infrastructure can have a positive influence on the quality of regulatory framework. "Attracting a wider, more diverse set of FDI firms is critical to the broader strategic framework of fighting state capture and corruption" (Hellman, Jones, and Kaufmann, 2002).

In addition to the abovementioned static econometric model, which represents the response of government effectiveness to current events, we also resort to a distributed-lag model using the lagged variable of oil rents as a percent of GDP to incorporate feedback over time. We predict that measuring the influence of oil rents with a time lag on government effectiveness can improve the

\footnotetext{
${ }^{9}$ An increase in human capital through technology spillovers from abroad is captured by instruction, education and training of employees to meet the higher standards. More precisely, multinational corporations (MNCs) in the host economy increase the degree of competition and force existing firms (including the inefficient ones) to make themselves more productive by investing in human capital (see Magnus Blomström, 1991). "MNCs also provide the training of labor and management which may then become available to the economy in general" (Magnus Blomström, 1991).
} 
significance of its coefficient. It is worthwhile to note that while creating "oil rents (\% of GDP) lagged one year" we will have T-1 year observations for each country, where T $=16$.

Since the years for which data are available differ, the estimates are done for an unbalanced panel. There is a lack of data for government effectiveness in 1997, 1999, and 2001 in each country. On the other hand, oil rents and total natural resources rents (\% of GDP) are not available in 2011. Hence, the observations of 16 years in our sample are reduced to 12 years for each country. Data on government effectiveness, oil rents and total natural resources rents (\% of GDP) are obtained from the World Bank. Data on GDP per capita and FDI stock are obtained from the European Bank for Reconstruction and Development (EBRD) and International Monetary Fund (IMF), respectively.

In order to estimate parameters from the panel data set, we resort to the methods of fixed effects and random effects. The choice between the two estimation methods will be discussed in the next section.

\section{Estimation Results}

Before delving into the discussions of estimation results, we analyze the partial correlation between government effectiveness and oil revenues visually. Partial correlation measures the degree of association between the two variables, with the effect of a set of controlling variables excluded. Therefore, we resort to scatter plots for Azerbaijan, Russia, Kazakhstan, and Turkmenistan given as below.

Figure 1: Government effectiveness versus oil rents, aggregate (partial relation).

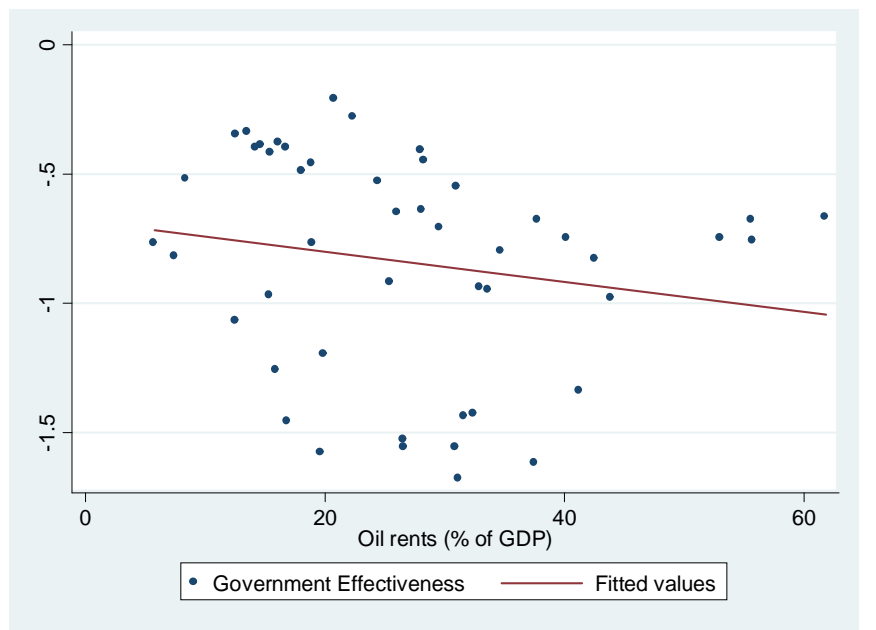

Source: The World Bank, the Worldwide Governance Indicators (1996-2011)

According to the aggregate scatter plot, government effectiveness is associated negatively with oil rents (\% of GDP). But the correlation (-0.1804) is not statistically significant. Thus, we do 
not get clear evidence from the cross-national sample. The graph suggests that the estimated relationship is driven by outlier observations and has clear departures from linearity. To clarify this relationship, we depict country-specific effects in Figure 2.

Figure 2: Government effectiveness versus oil rents (partial relation).
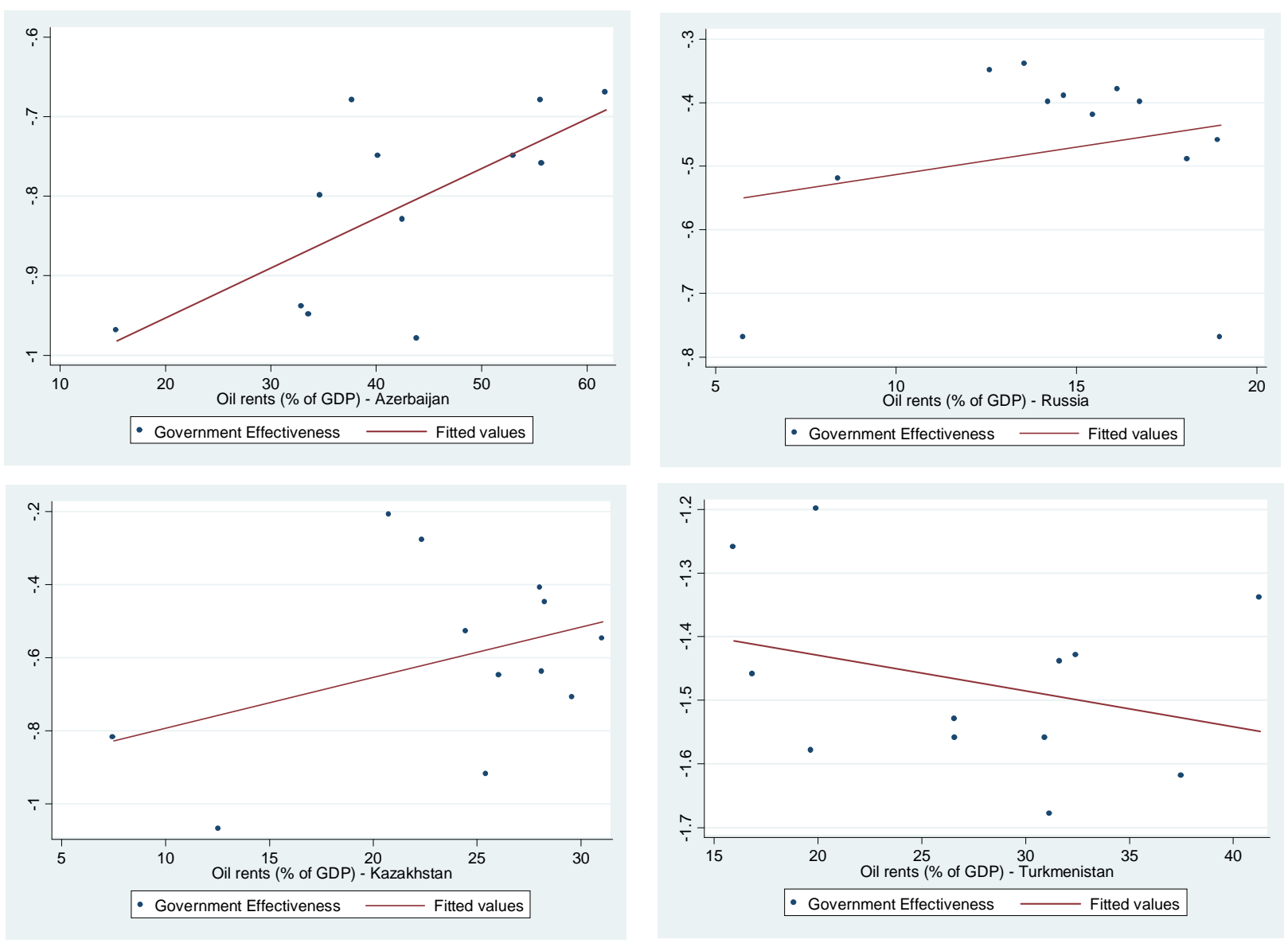

Source: The World Bank, the Worldwide Governance Indicators (1996-2011)

The negativity has been caused by the negative correlation of government effectiveness and oil revenues in Turkmenistan, whereas the data of both variables from Azerbaijan, Russia, and Kazakhstan have exhibited positive correlation. A negative tendency in Russia has been observed over the period 2002 to 2006, and a positive tendency has been observed starting from 2006. Although data for government effectiveness in 2001 is missing, we can judge that the negativity overlaps with the government change in Russia (2000 - 2008). The scatter plot for the total natural resources rents suggests that, in aggregate, revenues on total natural resources have a negative impact on government effectiveness as depicted in Figure 3. 
Figure 3: Government effectiveness versus total natural resources rents, aggregate (partial relation).

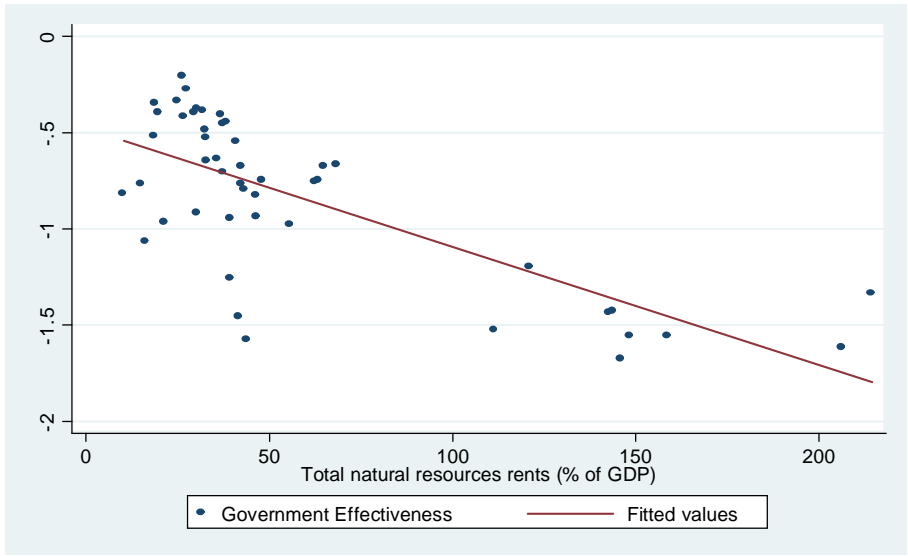

Source: The World Bank, the Worldwide Governance Indicators (1996-2011)

There is statistically significant correlation (-0.7318) at 5\%. It is worthwhile to note that this negativity has been caused by the negative correlation of both variables in Russia and Turkmenistan as depicted in Figure 4.

It seems that Turkmenistan's case is different from the cases of Azerbaijan and Kazakhstan, where oil revenues and total natural revenues exert negative influence on government effectiveness. As to the case of Russia, we assume that the negative tendency in government effectiveness has been caused by natural gas rents. The scatter plot for the correlation of government effectiveness and natural gas rents (\% of GDP) in Russia is depicted in Figure 5.

Our visual analysis of government effectiveness and resource revenues suggests that we should control for country specific effects. To justify this, we turn to econometric analysis to decide between two estimation methods: fixed effects and random effects. Initially, we run a Hausman test where the null hypothesis is that the preferred model is random affects versus the alternative the fixed effects. It basically tests whether the unique errors (ei) are correlated with the repressors (the null hypothesis is that they are not correlated). When the Hausman test rejects fixed effects and accepts random effects, we run Breusch and Pagan Lagrangian Multiplier (LM) test for random effects model. LM test helps us decide between a random effects regression and a simple OLS regression. The null hypothesis is that variances across entities are zero. That is, there is no evidence of significant differences across countries. Therefore, to overcome this dilemma, we report the results of both estimation approaches in Tables 3-4. 
Figure 4: Government effectiveness versus total natural resources rents (partial relation).
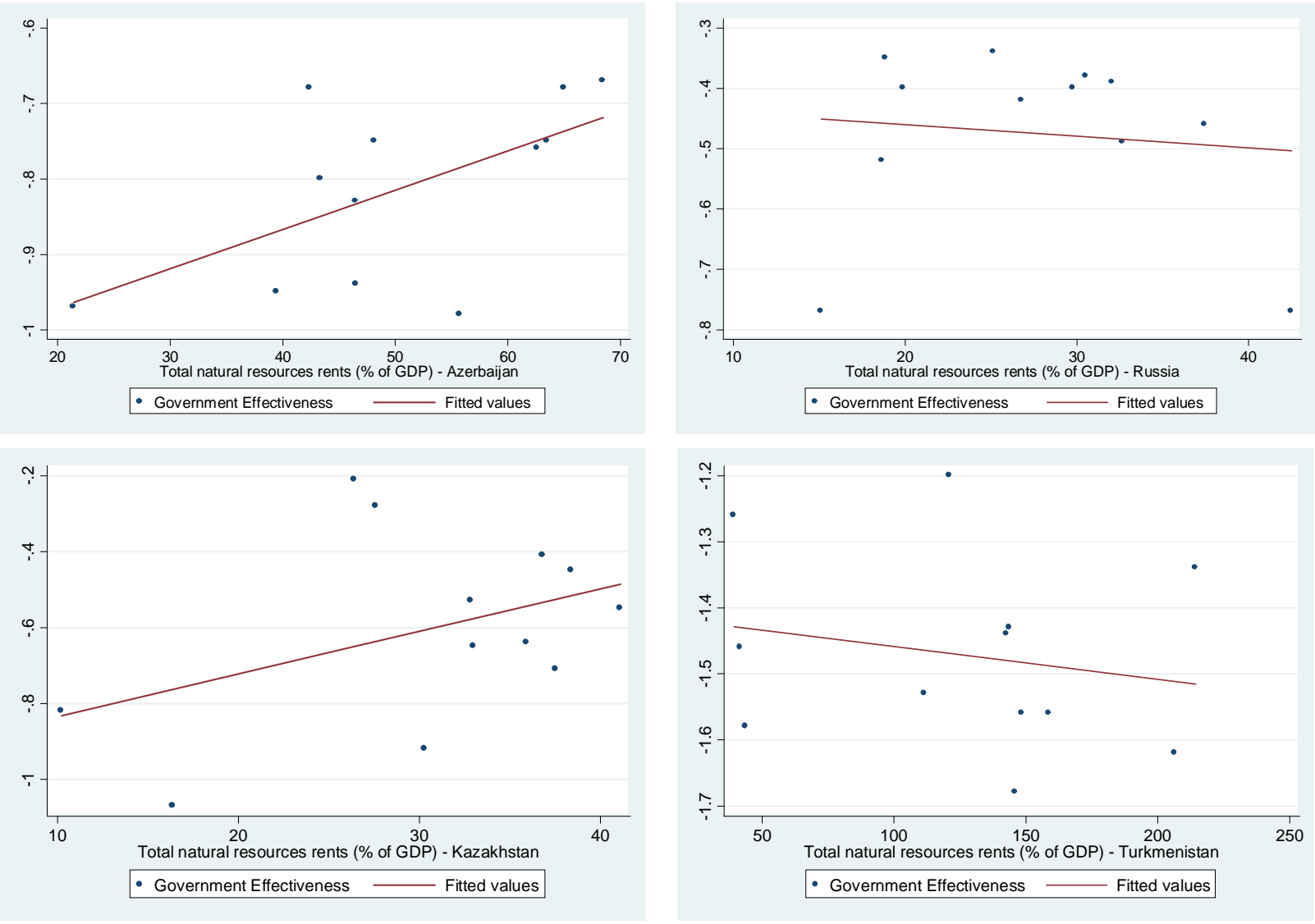

Source: The World Bank, the Worldwide Governance Indicators (1996-2011)

Figure 5: Government effectiveness versus natural gas rents, Russia (partial relation).

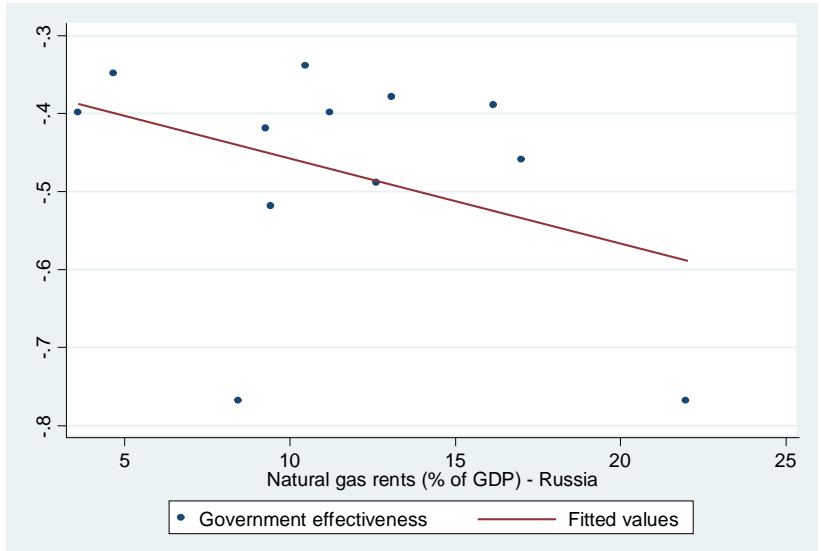

Source: The World Bank, the Worldwide Governance Indicators (1996-2011) 
Table 3: Government effectiveness as a dependent variable - unbalanced panel

\begin{tabular}{|c|c|c|c|c|c|c|c|c|c|}
\hline & $\overline{\mathrm{FE} \mathrm{(1)}}$ & $\overline{\text { FE (2) }}$ & 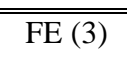 & FE (4) & $\overline{R E ~(1) ~}$ & $\overline{R E ~(2) ~}$ & RE (3) & $\overline{\mathrm{RE} \mathrm{(4)}}$ & $\overline{\text { OLS }}$ \\
\hline $\begin{array}{l}\text { Oil rents (\% of } \\
\text { GDP) }\end{array}$ & $\begin{array}{c}.0051 \\
(1.70)^{*}\end{array}$ & & & & $\begin{array}{l}.0048 \\
(1.63)\end{array}$ & & & & \\
\hline $\begin{array}{l}\text { Oil rents (\% of } \\
\text { GDP, lag) }\end{array}$ & & $\begin{array}{c}.0081 \\
(2.66)^{* *}\end{array}$ & $\begin{array}{l}.0037 \\
(1.07)\end{array}$ & $\begin{array}{l}.0036 \\
(1.03)\end{array}$ & & $\begin{array}{l}.0078 \\
(2.58) * * *\end{array}$ & $\begin{array}{c}.01086 \\
(2.70)^{* * *}\end{array}$ & $\begin{array}{c}.01378 \\
(3.73)^{* * *}\end{array}$ & $\begin{array}{l}.0137783 \\
(3.73)^{* * *}\end{array}$ \\
\hline GDP per capita & & & $\begin{array}{c}.0933 \\
(2.70)^{* *}\end{array}$ & $\begin{array}{c}.0991 \\
(2.70)^{* *}\end{array}$ & & & $\begin{array}{c}1.0858 \\
(11.26)^{* * * *}\end{array}$ & $\begin{array}{c}.8637 \\
(7.67)^{* * * *}\end{array}$ & $\begin{array}{l}.8637035 \\
(7.67)^{* * *}\end{array}$ \\
\hline $\begin{array}{l}\text { FDI stock (\% of } \\
\text { GDP, lag) }\end{array}$ & & & $\begin{array}{l}.1794 \\
(1.77)^{*}\end{array}$ & $\begin{array}{l}.1878 \\
(1.81)^{*}\end{array}$ & & & $\begin{array}{c}.9313 \\
(6.51)^{* * *}\end{array}$ & $\begin{array}{c}.9483 \\
(7.47)^{* * *}\end{array}$ & $\begin{array}{l}.9482503 \\
(7.47) * * *\end{array}$ \\
\hline Politics & & & & $\begin{array}{l}.01646 \\
(0.51)\end{array}$ & & & & $\begin{array}{l}.0280 \\
(3.03) * * *\end{array}$ & $\begin{array}{l}.0280465 \\
(3.03)^{* * * *}\end{array}$ \\
\hline $\begin{array}{l}\text { Observations } \\
\text { Prob> F } \\
\text { Hausman Test } \\
\text { Breusch\& Pagan }\end{array}$ & 48 & $\begin{array}{c}44 \\
0.0114\end{array}$ & $\begin{array}{c}44 \\
0.0020\end{array}$ & $\begin{array}{c}44 \\
0.0050\end{array}$ & $\begin{array}{c}48 \\
0.1027 \\
0.5924 \\
0.0000 \\
\end{array}$ & $\begin{array}{c}44 \\
0.0098 \\
0.4684 \\
0.0000 \\
\end{array}$ & $\begin{array}{c}44 \\
0.0000 \\
0.0165 \\
0.0293\end{array}$ & $\begin{array}{c}44 \\
0.0000 \\
0.0000 \\
0.8353 \\
\end{array}$ & $\begin{array}{c}44 \\
0.0000\end{array}$ \\
\hline
\end{tabular}

$\mathrm{t}$ statistics in brackets * significant at $10 \%$; ** significant at $5 \%$; *** significant at $1 \%$.

$\mathrm{P}$ values for Hausman and Breusch\& Pagan tests are given. The null hypothesis is rejected for p-value smaller than $10 \%$.

Time dummies have been included in RE (3), and RE (4) based on the tests for time dummies.

Table 4: Government effectiveness as a dependent variable.

\begin{tabular}{|c|c|c|c|c|c|c|c|c|c|}
\hline & FE (1) & FE (2) & (FE (3) & FE (4) & $\begin{array}{l}\mathrm{RE}(1) \\
\end{array}$ & RE (2) & $\begin{array}{l}\operatorname{RE}(3) \\
\end{array}$ & $\begin{array}{l}\text { RE (4) } \\
\end{array}$ & 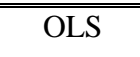 \\
\hline $\begin{array}{l}\text { Total Natural } \\
\text { Resource rents } \\
\text { (\% of GDP) }\end{array}$ & $\begin{array}{l}.00001 \\
(0.02)\end{array}$ & & & & $\begin{array}{c}.0049 \\
(-5.42)^{* * *}\end{array}$ & & & & \\
\hline $\begin{array}{l}\text { Total Natural } \\
\text { Resource rents } \\
\text { (\% of GDP, lag) }\end{array}$ & & $\begin{array}{l}-.00002 \\
(-0.02)\end{array}$ & $\begin{array}{l}-.0008 \\
(-0.96)\end{array}$ & $\begin{array}{l}-.0008 \\
(-0.99)\end{array}$ & & $\begin{array}{l}-.0061 \\
(- \\
6.55)^{* * *}\end{array}$ & $\begin{array}{c}-.0049 \\
(-4.09)^{* * *}\end{array}$ & $\begin{array}{c}-.0045 \\
(-3.73)^{* * *}\end{array}$ & $\begin{array}{c}-.0045 \\
(-3.73)^{* * *}\end{array}$ \\
\hline GDP per capita & & & $\begin{array}{c}.1213 \\
(4.11)^{* *} \\
*\end{array}$ & $\begin{array}{c}.1281 \\
(4.05)^{* * *}\end{array}$ & & & $\begin{array}{c}.4752 \\
(3.66)^{* * *}\end{array}$ & $\begin{array}{c}.4011 \\
(2.82)^{* *}\end{array}$ & $\begin{array}{c}.4011 \\
(2.82)^{* * *}\end{array}$ \\
\hline $\begin{array}{l}\text { FDI stock (\% of } \\
\text { GDP, lag) }\end{array}$ & & & $\begin{array}{l}.1592 \\
(1.57)\end{array}$ & $\begin{array}{l}.1695 \\
.1 .64)\end{array}$ & & & $\begin{array}{c}4068 \\
(2.14)^{* *}\end{array}$ & $\begin{array}{c}.4597 \\
(2.38)^{* *}\end{array}$ & $\begin{array}{c}.4597 \\
(2.38)^{* *}\end{array}$ \\
\hline Politics & & & & $\begin{array}{l}.0202 \\
(0.63)\end{array}$ & & & & $\begin{array}{l}.0111 \\
(1.21)\end{array}$ & $\begin{array}{l}.0111 \\
(1.21)\end{array}$ \\
\hline Observations & 48 & 44 & 44 & 44 & 48 & 44 & 44 & 44 & 44 \\
\hline Prob> F & 0.9876 & 0.9829 & 0.0022 & 0.0052 & 0.0000 & 0.0000 & 0.0000 & 0.0000 & 0.0000 \\
\hline Hausman Test & & & & & - & 0.0000 & 0.0119 & 0.0649 & \\
\hline Breusch\& Pagan & & & & & 0.0033 & 0.0480 & 0.4677 & 0.6894 & \\
\hline
\end{tabular}

t statistics in brackets * significant at $10 \%$; ** significant at $5 \% ; * * *$ significant at $1 \%$.

$\mathrm{P}$ values for Hausman and Breusch \& Pagan tests are given. The null hypothesis is rejected for p-value smaller than $10 \%$.

Time dummies have been included RE (3), and RE (4) based on the tests for time dummies.

Our findings suggest that oil rents (\% of GDP) exert positive impact on government effectiveness in both estimation approaches. In contrast, total natural resources rents (\% of GDP) are 
negatively associated with government effectiveness. It should be no surprise that this negativity has been generated by the data of Russia and Turkmenistan. We obtain statistically significant coefficients while using random effects estimations and the results are robust. By robustness we mean that no matter if any of the other explanatory variables are excluded from the main equation, the explanatory variable still keeps its sign and significant level.

In both estimations, we do not find any reliable evidence on the impact of political stability on government effectiveness. It should be noted that only Russia has a positive polity IV score of 6 (close to democracy), which has decreased to 4 starting from 2007. The other countries in our sample have kept the negative sign as constant: Azerbaijan (-7), Kazakhstan (-6), and Turkmenistan (-9). Therefore, the impact of democracy proxied by polity IV is ambiguous.

We also find clear evidence on the impact of GDP per capita and FDI stock. The results suggest that an increase in economic development and the realization of spillovers through foreign investment are highly associated with the effectiveness of the government.

Once we have found the association between government effectiveness and resource rents using panel data analysis, we can rank the countries in terms of government effectiveness (see Figure 6).

Figure 6: Country rankings in terms of government effectiveness.
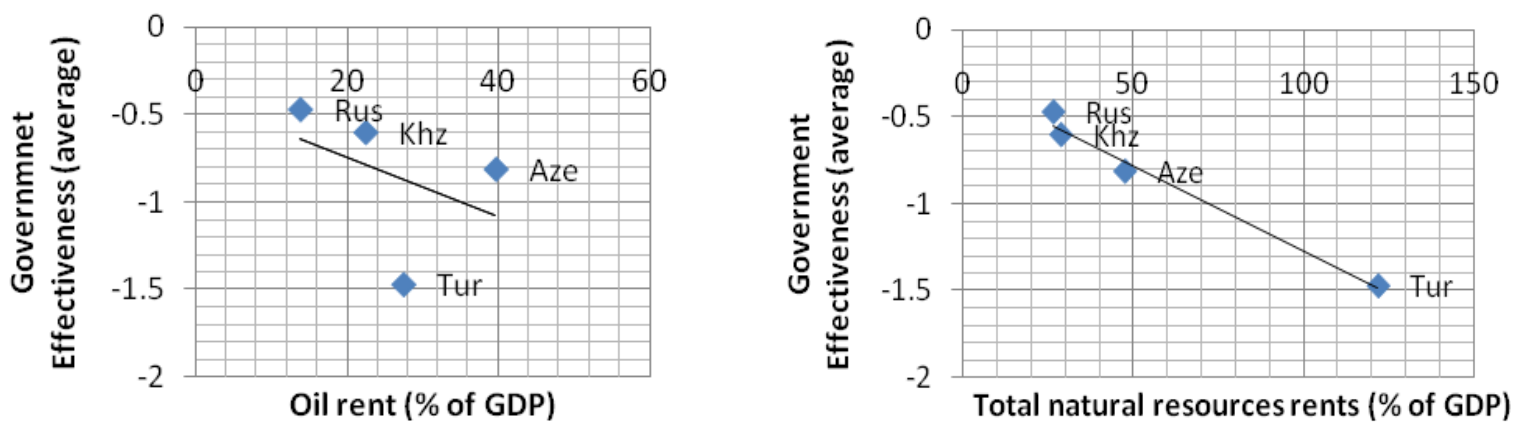

Source: The World Bank, the Worldwide Governance Indicators (1996-2011)

As shown through the scatter plots (Figure 6), countries with higher average oil rents $(\%$ of GDP) and total natural resource rents (\% of GDP) have lower rates of government effectiveness. In ranking from high to low government effectiveness, the countries can be classified as follows: Russia, Kazakhstan, Azerbaijan and Turkmenistan. It indicates that, in general, a negative association is present. However, based on our analysis of Azerbaijan, Kazakhstan and Russia, we can predict that this negativity in the region will shift to a positive tendency in the future. 


\section{Discussion}

Institutions are among the main sustainable growth and development determinants in post-Soviet resource-rich countries. The main evidence of this study is that the impact of the main resourcerelated indicators on institutional quality is negative. The one exception is Russia, where oil rents impacted the quality of institutions positively while the impact of total natural resources on institutional quality is slightly negative. As we can see from Figure 1 (which shows trends of oil-gas rents as percentage in GDP), natural gas rents also play a crucial role in the total resource dependence of Russia despite its declining trend. Excluding Turkmenistan, in other resource-rich post-Soviet countries, the weight of oil rents in GDP exceed the ratio of natural gas rents in GDP.

Figure 7: Dynamics of oil and gas rents in resource-rich CIS countries.
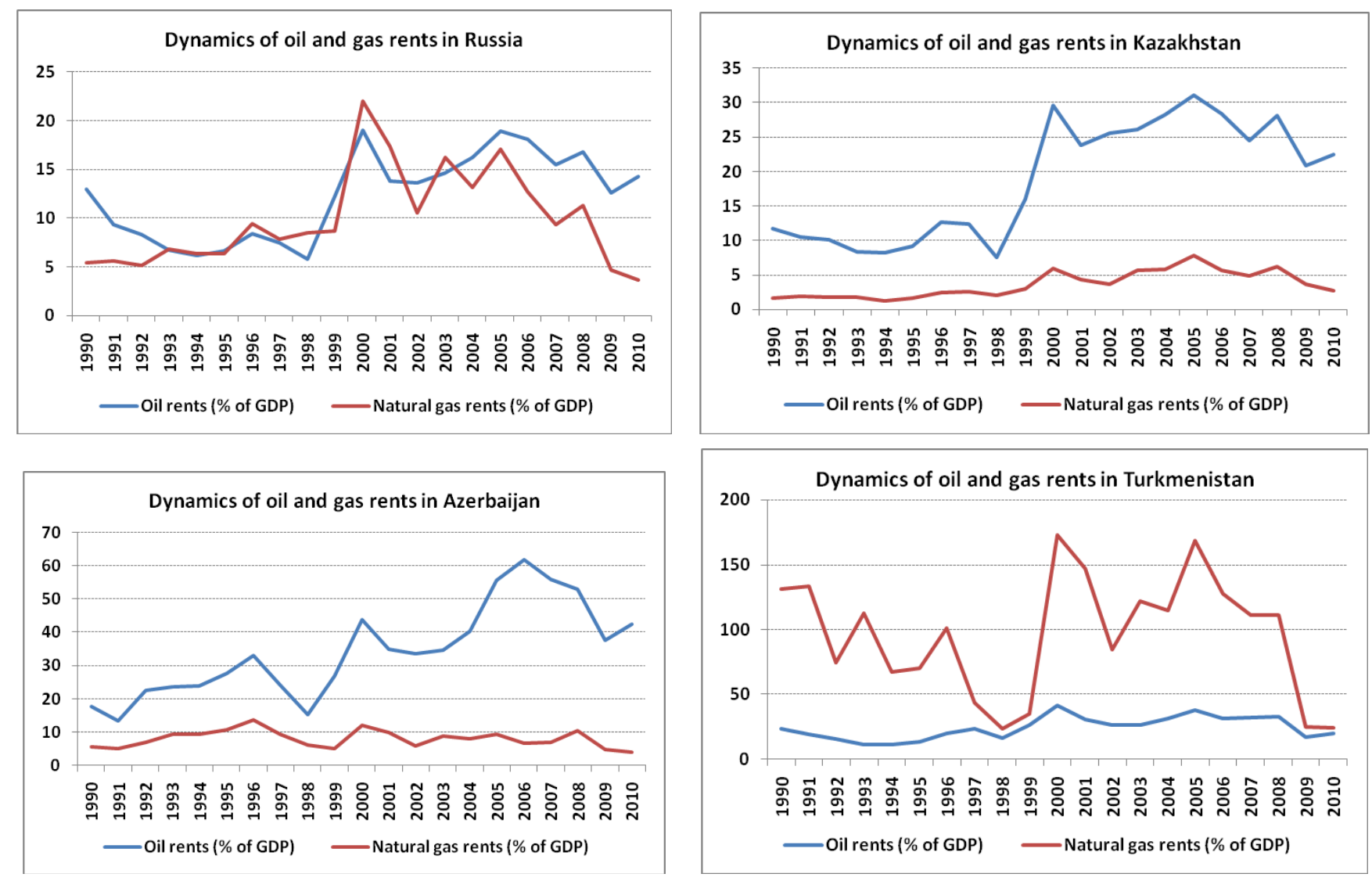

Source: WB Metadata, authors' calculations

Aidis and Estrin (2006) revealed that "after a catastrophic period of macro-economic performance immediately subsequent to transition, the Russian economy had begun to recover during the mid-1990s and subsequent increases in the price of oil and other raw materials inaugurated a long period of relatively fast growth in Russia, from 1999, which has been maintained until this day" 
(2006). High energy prices have helped stabilize resource-rich post-Soviet countries (Russia, Kazakhstan, Azerbaijan, and Turkmenistan - "Geo-economic heartland") internally and temporarily. But in the long run, hazardous dependence on natural resources led to negative consequences and challenges for these countries including improper functioning of a bureaucracy and state failure. In the "Failed States Index" for 2012, these four countries are under a "high warning" that they may fall into the failed states group. ${ }^{10}$ "State legitimacy" (corruption, government effectiveness, political participation, electoral process, level of democracy, illicit economy, power struggles, etc.) is especially considered problematic; the fact has been stated that in this country group "corruption and a lack of representativeness in the government directly undermine the social contract."

The Bertelsmann Stiftung's Transformation Index (BTI) is the cross-national comparative index that uses self-collected data to measure the quality of governance and provide a comprehensive analysis of countries' policymaking success during processes of transition. BTI 2012 identified that stability of democratic institutions, rule of law, property rights, political participation and integration can be characterized as breakable in resource-rich post-Soviet countries. In accordance with BTI 2012, "democratic institutions exist on paper and function well but within the framework of a semi-authoritarian regime in Azerbaijan," "no functioning democratic institutions exist in Turkmenistan," and "Kazakhstan's regime continues to be authoritarian rather than democratic, and the review period confirmed the country on this authoritarian path." Only in Russia "the democratic institutions foreseen in the constitution do all exist and perform their function in principle." ${ }^{11}$

\footnotetext{
${ }^{10} \mathrm{http}$ // www.fundforpeace.org/global/library/cfsir1210-failedstatesindex2012-06p.pdf

${ }^{11} \mathrm{http}: / /$ www.bti-project.org/country-reports/pse/
} 
Figure 8: Bertelsmann Transformation Index 2012.

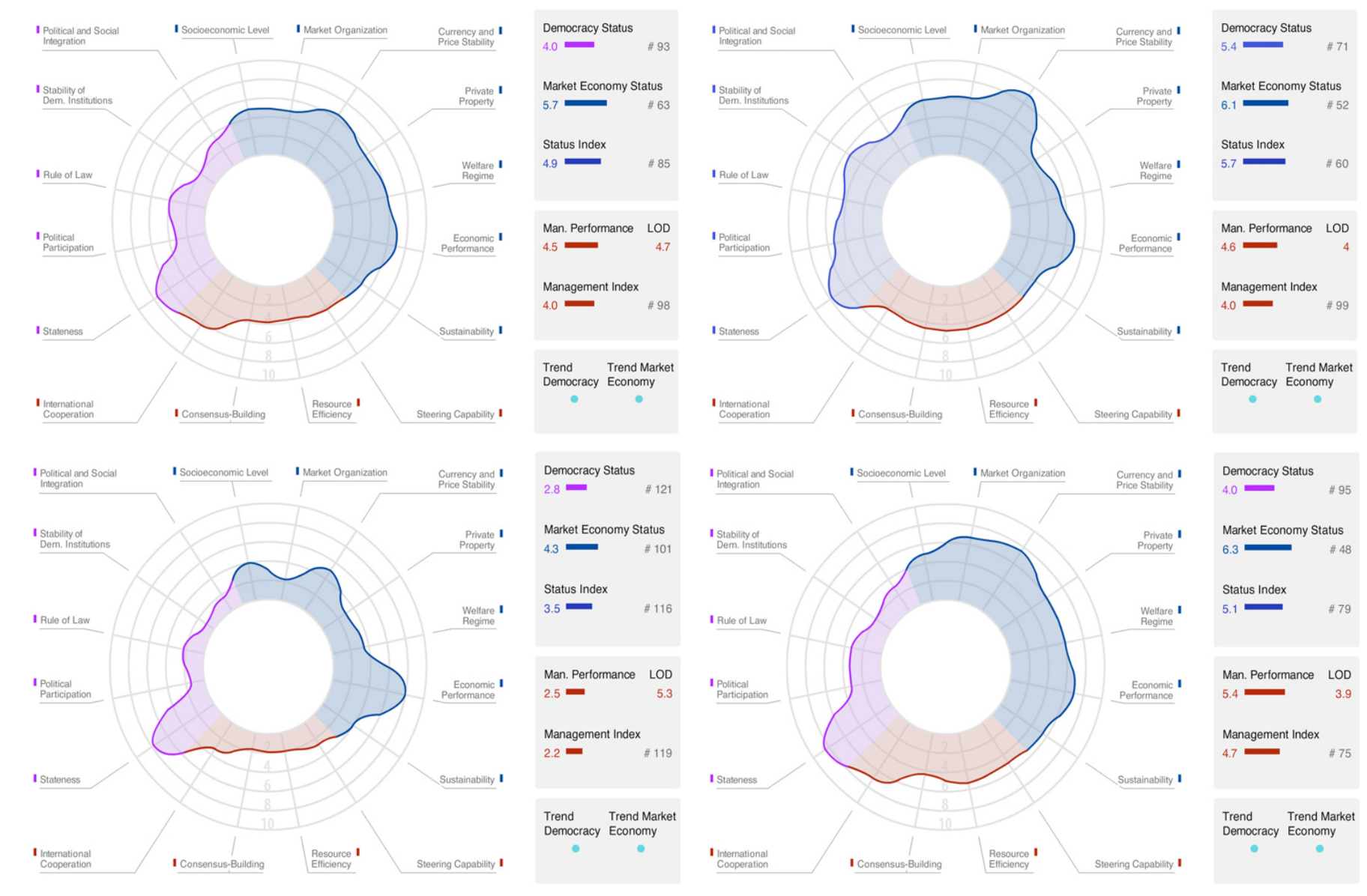

Source: http://www.bti-project.org

Index of Economic Freedom also emphasized the role of effective institutions in development and ensuring economic freedom. It has identified four broad categories of economic freedom:

Index of Economic Freedom also emphasized the role of effective institutions in development and ensuring economic freedom. It has identified four broad categories of economic freedom:

(i) Rule of law (property rights, freedom from corruption);

(ii) Limited government (fiscal freedom, government spending);

(iii) Regulatory efficiency (business freedom, labor freedom, monetary freedom);

(iv) Open markets (trade freedom, investment freedom, and financial freedom).

Due to Index of Economic Freedom 2012, "substantial challenges remain, particularly in implementing deeper institutional and systemic reforms that are critical to strengthening the foundations of economic freedom in Azerbaijan. Institutional shortcomings such as a weak judicial system and widespread corruption hold down diversification and modernization in Kazakhstan. The Russian government has demonstrated little if any commitment to economic reform in recent years and 
strong returns from hydrocarbons have buoyed the economy, prospects for sustained long-term growth and diversification remain dim. In Turkmenistan, vibrant economic growth is severely constrained by long-standing institutional weaknesses that undermine the foundations of economic freedom and heavy state involvement in the leading economic sectors has dampened private-sector dynamism and has led to economic stagnation in non-hydrocarbon sectors." 12

Taking into accounts that the main source of public finance in these countries is exhaustible oil-gas revenues, the quality of budgetary oversight institutions is very crucial. Certain rules and procedures govern these institutions' integration into the decision-making process, such as the necessity for a budget debate in the parliament and parliament budgetary approval. But Open Budget Survey (OBS) (as the only independent, comparative, regular measure of budget transparency and accountability around the world) also distinguished the capacity of oversight institutions in Russia from other countries in the region in a positive manner. According to the Open Budget Survey 2010, the budget oversight provided by Russia's legislature is generally strong, but it does not allow the public to be present during legislative hearings at which the executive testifies on its proposed budget. Budget oversight provided by Russia's supreme audit institution (SAI) also is generally strong, but it does not have adequate reporting on the follow-up steps taken by the executive to address audit recommendations. Budget oversight provided by Kazakhstan's legislature and SAI are inadequate because it does not hold open budget discussions at which the public can testify and because it is not fully independent from the executive. Budget oversight provided by Azerbaijan's legislature is inadequate because it does not have full power to amend the budget proposal. Oversight provided by Azerbaijan's SAI is weak due to the lack of complete discretion in law to choose what to audit and lack of sufficient resources to meaningfully exercise its mandate. ${ }^{13}$ This is also a valid argument that under-developed state capacities increased the incentives for states to capture more rents and oil-gas nationalization (see Ahrend and Tompson, 2006).

Due to BTI 2012 "rising revenues from the export of oil and gas provide the economic potential for transformation." Generally, it is a straightforward supposition that oil-gas rents will lead to weak institutional quality, if they do not lead to a positive determinant for drastic reforms at the same time. A great deal of empirical evidence in the existing literature on the relationship between oil-gas rents and changes in institutional quality finds no indubitable statistical causality between the two. But we found that total natural resources rents as a percentage in GDP in four resourcerich post-Soviet countries have a negative relationship with government effectiveness. ${ }^{14}$ Our study provides the framework for future studies to assess the quality of institutions in resource-rich

\footnotetext{
${ }^{12} \mathrm{http} / / /$ www.heritage.org/index/pdf/2012/book/index_2012.pdf

${ }^{13} \mathrm{http}: / /$ internationalbudget.org/what-we-do/open-budget-survey/country-info/

${ }^{14}$ World Bank defines "oil rents" as the difference between the value of crude oil production at world prices and total costs of production, "natural gas rents" as the difference between the value of natural gas production at world prices and total costs of production, and "total natural resources rents" as the sum of oil rents, natural gas rents, coal rents, mineral rents, and forest rents.
} 
countries.

\section{Conclusion}

This paper presents a comprehensive assessment of the linkage between institutional quality and resource dependence in resource-rich transition countries of the Caspian basin - particularly Azerbaijan, Kazakhstan, Russia and Turkmenistan. Drawing on multiple sources, the paper assembles a comprehensive set of information to date pertaining to the institutional quality for diverse countries of this region, both in terms of country background and levels of economic development. Also, using a panel dataset containing information on government effectiveness, we establish the determinants of government effectiveness in Azerbaijan, Russia, Kazakhstan, and Turkmenistan over the period of 1996 to 2011. A two-way causal link between the two is also well-recognized in the existing literature. The various combinations of variables were compared experimentally. Once we found the association between government effectiveness and resource rents using panel data analysis, then we could rank the countries in terms of government effectiveness. The analysis for the total natural resource rents suggests that, in aggregate, revenues on total natural resources have a negative impact on government effectiveness. The countries with higher average oil rents $(\%$ of GDP) and total natural resource rents (\% of GDP) have lower rates of government effectiveness. This finding is promising and should be explored with other resource-rich countries. Our results are encouraging and should be validated in a larger set of relevant data which directly and indirectly relates to quality of governance and government effectiveness. These results provide compelling evidence that there is a direct undue influence among variables related to resource abundance and institutional quality. An applied approach in this study can be used in the identification of institutional aspects of the "resource curse" concept. Our study provides the framework for future studies to assess the quality of institutions in resource-rich countries, but has also raised some serious questions. One of the important questions for future studies is to define the mutual influence channels between institutional quality and natural resource dependence using multidimensional variables. 


\section{References}

[1] Ahrend, R., and Tompson, W. (2006) "Realising the oil supply potential of the CIS: the impact of institutions and policies" OECD Economics Department Working Papers, No. 484.

[2] Aidis, R., and Estrin, S. (2006) "Institutions, Networks and Entrepreneurship Development in Russia: An Exploration" William Davidson Institute Working Paper Number 833.

[3] Alonso, J. A., and Garcimartín, C. (2009) "The Determinants of Institutional Quality. More on the Debate" CREDIT Research Paper, No. 09/04

[4] Arezki, R., Hamilton, K., and Kazimov, K. (2011) "Resource Windfalls, Macroeconomic Stability and Growth: The Role of Political Institutions" IMF Working Paper (WP/11/142).

[5] Barma, N.H., Kaiser, K., Le, T.M., and Viñuela, L. (2012) "Rents to riches? The political economy of natural resource-led development" World Bank.

[6] Blomstrom, M. (1991) "Host country benefits of foreign investment" NBER Working Papers 3615, Cambridge, USA.

[7] Brunnschweiler, C.N, and Bulte, E.H. (2008) "Natural Resources and Violent Conflict: Resource Abundance, Dependence and the Onset of Civil Wars" CER-ETH - Center of Economic Research at ETH Zurich, Working Paper 08/78

[8] Cherif, R., and Hasanov, F. (2012) "Oil Exporters' Dilemma: How Much to Save and How Much to Invest" IMF Working Paper (WP/12/4).

[9] Clifford G. Gaddy and Barry W. Ickes (2011) "The Challenge of Managing Rent Addiction." Russia in 2020: Scenarios for the future. Ch.9, Carnegie Endowment for International Peace.

[10] Collier, P., and Hoeffler, A. (1998) "On the Economic Causes of Civil War" Oxford Economic Papers, 50:563-73.

[11] Collier, P., and Hoeffler, A. (2007) "Unintended Consequences: Does Aid Promote Arms Races?" Oxford Bulletin of Economics and Statistics 69: 1-28.

[12] Colton, T., and Holmes, S. eds. (2006) The State After Communism: Governance in the New Russia. Lanham: Rowman and Littlefield.

[13] Easter, G. (2008) "The Russian State in the Time of Putin" Post-Soviet Affairs, 24, no 3 (2008), 199-230

[14] Gelman, V. (2011) "Institution Building and 'Institutional Traps' in Russian Politics", Russia in 2020: Scenarios for the future. Ch.11, Carnegie Endowment for International Peace, 2011 
[15] Gelman, V., and Marganiya, O. (2010) "Resource Curse amd Post-Soviet Eurasia: Oil, Gas and Modernization" Rowman \& Littlefield Publishers, Incorporated.

[16] Globerman, S., and Shapiro, D. (2002) "Global foreign direct investment flows: the role of governance infrastructure" World Development, 30, 11, pp1899-1920

[17] Greif, A. (2006) "Institutions and the Path to Modern Economy" Lessons from Medieval Trade, Cambridge, Cambridge University Press.

[18] Gwartney, J.D., Holcombe, R.G., and Lawson, R.A. (2004) "Economic freedom, institutional quality, and cross-country differences in income and growth" Cato Journal, Vol. 24, No. 3.

[19] Heinrich, A. (2012) "Introduction: Political Challenges of a Resource Boom" Palgrave Macmillian.

[20] Hellman, J. (1998) "Winners Take all: The Politics in Partial Reforms in Post-Communist Transitions" World Politics, 50, no. 2, 203-34

[21] Hellman, J., Jones, G., and Kaufmann, D. (2000) "Beyond the 'Grabbing Hand' of Government in Transition: Facing up to 'State Capture' by the Corporate Sector" Transition.

[22] Hellman, J., Jones, G., and Kaufmann, D. (2002). "Far From Home: Do Foreign Investors Import Higher Standards of Governance in Transition Economies?" Policy Research Working Paper, The World Bank: Washington, D.C.

[23] Jensen, N., and Wantchekon, N. (2004) "Resource Wealth and Political Regimes in Africa" Comparative Political Studies, September, 37: 816-841.

[24] Kaufmann, D., Kraay, A., and Mastruzzi, M. (2010) "The Worldwide Governance Indicators: Methodology and Analytical Issues" World Bank, Policy Research Working Paper 5430

[25] Kirkpatrick, C., Parker, D., and Zhang, Y. (2006) "Foreign direct investment in infrastructure in developing countries: does regulation make a difference?" Transnational Corporations, Vol. 15, No. 1.

[26] Leite, C. and Weidmann, J. (2002) "Does Mother Nature Corrupt? Natural Resources, Corruption, and Economic Growth" in G. T. Abed and S. Gupta (Eds.), Governance, Corruption and Economic Performane, pp. 71/99, International Monetary Fund.

[27] Lujala, P., Gleditsch, N.P., and Gilmore, E. (2005) "Diamond Curse: Civil War and a Lootable Resource" Journal of Conflict Resolution; 49; 538

[28] Luong, P.J., and Weinthal, E. (2010) "Oils is not a curse: Ownership Structure and Institutions in Soviet Successor States" Cambridge University press. 
[29] Mehlum, H., Moene, K. and Torvik, R. (2005) "Cursed by resources or institutions?" Norwegian University of Science and Technology, Department of Economics, Working Paper Series No. 10

[30] Mehlum, H., Moene, K., and Torvik, R. (2006) "Institutions and the resource curse" Economic Journal, 116 (January), 1-20. Royal Economic Society 2006, Blackwell Publishing.

[31] Mehrara, M., Alhosseini, S.M.S., and Bahramirad, D. (2011) "Resource Curse and Institutional Quality in Oil Countries" Middle Eastern Finance and Economics Journal Issue 9.

[32] North, D. (1990) "Institutions, Institutional Changes and Economic Performances" (Cambridge: Cambridge University Press), p.16

[33] North, D. (1991) "Institutions" The Journal of Economic Perspectives, Vol. 5, No. 1. (Winter, 1991), pp. 97-112.

[34] Polterovich, V., Popov, V., and Tonis, A (2008) "Mechanisms of Resource Curse, Economic Policy and Growth" New Economic School, working paper \# WP/2008/000

[35] Porter , M.E., Schwab, K., Sala-i-Martin, X., and Lopez-Claros, A. (2004) "The Global Competitiveness Report: 2003-04", Oxford University Press.

[36] Porter, M.E. (2004) "Building the Microeconomic Foundations of Prosperity: Findings from the Business Competitiveness Index", chapter 1.2, The Global Competitiveness Report: 200304.

[37] Qian, R. (2012) "Why Do Some Countries Default More Often Than Others? The Role of Institutions" World Bank, Policy Research Working Paper 5993.

[38] Rogov, K. (2011) "The 'Third Cycle': Is Russia Headed Back to the Future? Russia in 2020: Scenarios for the future." Ch.7, Carnegie Endowment for International Peace.

[39] Rosa, D., and Iootty, M. (2012) "Are Natural Resources Cursed? An Investigation of the Dynamic Effects of Resource Dependence on Institutional Quality" World Bank, Policy Research Working Paper 6151.

[40] Ross, M.L. (2004) "How Do Natural Resources Influence Civil War? Evidence from Thirteen Cases" International Organization, Volume 58, Issue 01, pp 35-67

[41] Ross, M.L. (2012) "Oil curse: how petroleum wealth shapes the development of nations" Princeton University Press, 2012 (page 208-212).

[42] Sachs, J.D, and Warner, A.M. (1997) "Natural resource abundance and economic growth" Center for International Development and Harvard Institute for International Development, November. 
[43] Volkov, V. (2002) "Violent Entrepreneurs: The Role of Force in the Making Russian Capitalism" (Ithaca, N.Y: Cornel University Press.

[44] Zhuang, J., Dios, E., and Lagman-Martin, A. (2010) "Governance and Institutional Quality and the Links with Economic Growth and Income Inequality: With Special Reference to Developing Asia", ADB Economics Working Paper Series No. 193.

[45] http://www.rand.org/blog/2012/04/book-review-why-nations-fail-by-daron-acemogluand.html

[46] http://www.fundforpeace.org/global/library/cfsir1210-failedstatesindex2012-06p.pdf

[47] http://www.bti-project.org/country-reports/pse/

[48] http://www.heritage.org/index/pdf/2012/book/index_2012.pdf

[49] http://internationalbudget.org/what-we-do/open-budget-survey/country-info/

[50] http://www.economist.com/news/leaders/21571136-politicians-both-right-and-left-couldlearn-nordic-countries-next-supermodel

[51] Regional Economic Prospects in EBRD Countries of Operations: October 2012.

[52] Regional Economic Prospects in EBRD Countries of Operations: January 2013.

[53] EBRD Transition Report 2010: Recovery and Reform

[54] UNICEF Country Profile 2010: Education in Azerbaijan

[55] IMF World Economic Outlook Database, 2013 